Марија В. Радуловић

marijaradulovic3@gmail.com

Тања М. Вуковић

vukovic.tanja1@gmail.com

Градска библиотека

„Владислав Петковић Дис” Чачак
Стручни рад

UDK 027.54(497.11)"2020"

616.98:578.834(100)"2020"

https://doi.org/10.18485/bibliotekar.2020.62.2.6

\title{
ПРОГРАМСКИ ИСКОРАК У ОНЛАЈН СВЕТ
}

\section{Рад Градске библиотеке Чачак за време пандемије вируса корона}

Сажетак: Од увођења ванредног стања у Републици Србији због пандемије вируса корона, многе ствари су се промениле и у области културе. Иако погођене отказивањем различитих садржаја: манифестација, књижевних вечери, промоција, изложби, трибина, радионица итд. и пред јавне библиотеке постављен је задатак како да што ефикасније преброде кризу и не одустану од своје мисије. У раду је приказано пословање Градске библиотеке „Владислав Петковић Дис” у Чачку, у периоду март-септембар 2020. године, са посебним нагласком на програмским активностима које су организоване у новонасталим околностима изазваних здравственом ситуацијом. А поред осталог наведено је и како су неке од српских библиотека недостајућу програмску активност надоместиле искораком у онлајн свети. Поставши креатор нових услуга и вредности и Градска библиотека Чачак осмислила је летњу програмску шему „Начуљи уши, читам ти причу!” која је емитована на Фејсбук страници и Јутјуб каналу установе ${ }^{1}$ током августа и септембра. Новом летњом шемом настављен је континуитет рада, проширен опсег програмских активности, омогућена је доступност културе и културних садржаја и у време када је окупљање публике једино било могуће организовати на друштвеним мрежама и интернету. Овом акцијом, и њој сличним, јавности се шаље јасна порука да се култура не може заустиавитии.

Кључне речи: Градска библиотека Чачак, вирус корона, онлајн програм, друштвене мреже, програмска активност, аудио-запис

Градска библиотека Чачак, https://www.youtube.com/user/bibliotekacacak (преузето 11. 8. 2020). 


\section{Увод}

На глобалном нивоу догодиле су се значајне промене у 2020. години појавом пандемије вируса корона, што је трансформисало битне друштвене парадигме. Без улепшавања, показане су многе мањкавости система у свим областима живота: здравственом, политичком, економском, образовном, културном итд. Пред већину је постављен тежак задатак како у новонасталим околностима реаговати и организовати живот и рад. На основу претходних искустава када су пандемије мењале ток историје, али биле и окидач за различите иновације, и ову кризу требало би, колико је то изводљиво, сагледати као могући подстицај за креативна решења. Глобални проблеми и питања организације пословања и функционисања у условима који су захтевали потпуну реорганизацију рада пренети су и на локални ниво у свим секторима, па и у култури. Установе су почеле да се суочавају са сличним питањима и биле су принуђене да се прилагоде актуелним околностима.

\section{Рад чачанске Библиотеке за време пандемије вируса корона}

У складу са одлуком Владе Републике Србије о забрани окупљања на јавним местима ${ }^{2}$, а у вези са актуелном здравственом ситуацијом и ради спречавања појаве и ширења вируса корона, Градска библиотека „Владислав Петковић Дис" 12. марта 2020. отказала је програме предвиђене да се одрже до краја месеца. Четири дана касније уведено је ванредно стање у РС и обустављен је рад са корисницима у свим одељењима и огранцима. Члановима је било омогућено да током радног времена Библиотеке (запослени су били распоређени по групама на дежурствима која су трајала 24 сата) продуже рок позајмице позивом на контакт телефон, врате позајмљене књиге на наменском пулту испред главног улаза или да са доступних полица Отворене библиотеке за чије коришћење није била потребна чланска карта, користе грађу.

Друга полица Отворене библиотеке била је смештена у популарну спортску дворану „Плава хала” у Атеници која је, одлуком Кризног штаба за ванредне ситуације и Радног тима, постала привремена болница за

Влада Републике Србије, „Стриктно поштовати забрану окупљања” https://www.srbija.gov. rs/vest/450393/striktno-postovati-zabranu-okupljanja.php (преузето 25. 8. 2020). 
оболеле од вируса корона са лакшом клиничком сликом. Градска библиотека се побринула да им време уз књигу што квалитетније и брже прође, те су пацијенти током опоравка били у прилици да користе фонд од 300 књига отписаних из фонда Позајмног одељења за одрасле.

Поштујући препоруке ресорног министарства да установе културе постављају материјале у дигиталном облику, чачанска Библиотека је изместила део културних садржаја на друштвене мреже и интернет канале под слоганом „Култура је пола здравља” и на тај начин, не прекидајући контакт са публиком, оплеменила је време које су људи проводили код својих кућа.

Иако су програми у оквиру 57. Дисовог пролећа (које традиционално почиње у марту, а завршава се крајем маја) били одгођени, сви конкурси у оквиру песничке манифестације расписани су на време и највећим делом су реализовани електронским путем. Крајем априла, након електронске седнице жирија, објављено је име добитника Дисове награде.

На основу Одлуке о укидању ванредног стања, ${ }^{3}$ а у вези са Обавешиетьем о руковаюу ірађом у условима йандемије Вируса САРС-КоВ-2 Народне библиотеке Србије, директор Градске библиотеке „Владислав Петковић Дис", доноси одлуку о наставку рада са корисницима од 8. маја.

Захваљујући бољој епидемиолошкој ситуацији и попуштању мера, половином јуна Градска библиотека успела је да реализује завршницу 57. Дисовог пролећа са четири различита програма. Свечаност доделе награда у оквиру манифестације Дисово пролеће одржана је 26. јуна, након чега је планирана реализација летњих садржаја (радионице за децу и младе, музичке радионице, концерти на отвореном, летњи биоскоп итд.), међутим 3. јула је уведена ванредна ситуација на територији Града Чачка одлуком градоначелника, на предлог Градског штаба за ванредне ситуације, и то је условило отказивање свих програмских активности.

С обзиром на то и на основу истраживања да се библиотерапијом може утицати на смањење негативних ефеката пандемије вируса корона, Библиотека уводи нову услугу „Библиотерапија” - достава књига на кућну адресу.

Још од 1916. године користи се кованица библиоиеерайија, а осмислио ју је Семјуел Кротерс (Samuel Crothers) и употребио у часопису „Atlantic Monthly”. Библиотерапија подразумева читање одабраних текстова, разговор о прочитаном са циљем унапређења личног раста и развоја.

Правно-информациони систем РС, „Одлука о укидању ванредног стања: 65/2020-4”, https:// www.pravno-informacioni-sistem.rs/SlGlasnikPortal/eli/rep/sgrs/skupstina/odluka/2020/65/1/ reg (преузето, 3. 8. 2020). 
Превентивна или развојна библиотерапија намењена је људима као помоћ у превазилажењу свакодневних проблема, стицању самопоуздања, побољшању комуникације, духовном развоју, креативном и критичком размишљању итд. ${ }^{4}$ Сервис Градске библиотеке „Библиотерапија” реализује се као јавни рад захваљујући Граду Чачку и НС3, и траје четири месеца, до октобра 2020. Јавним радом настоји се да се корисницима Библиотеке на територији Града Чачка олакша приступ жељеним насловима пружањем библиотечко-информационих услуга до кућне адресе. Тиме се смањују дугорочни неповољни ефекти пандемије као што су друштвено отуђење, усамљеност, социјална затвореност, неповерење итд.

Након увођења ванредне ситуације и програмске активности су поново отказане, па се интензивно размишљало који би садржај могао да окупи и повеже више људи без њиховог физичког присуства. Важно је било придржавати се свих прописаних мера ради спречавања ширења вируса корона, али било је битно и да публика не остане ускраћена за културне садржаје.

Стога је Градска библиотека у 11. августа покренула летњу програмску шему емитовањем аудио-записа прича на Фејсбук страници и Јутјуб каналу установе, сваког уторка, четвртка и суботе од 21 час.

\section{Библиотека као креатор нових услуга и вредности}

Након пандемија (куга, колера, тифус, шпанска грозница, птичји грип, САРС итд.) које су мењале свет, и вирус корона се може посматрати као свеобухватни друштвени феномен који је утицао на велике промене у политици, економији, религији, науци, образовању, па и у култури. Поред мноштва негативних ефеката пандемије и нарушавања здравља појединаца и група, она може бити и покретач позитивних импулса и креативних решења.

„Футуролог Матијас Хоркс (Matthias Horx) сматра да се човечанство налази на прекретници, у йренуйку који мења смер буgућносиии. Он не само да закључује да се тренутно на многим подручјима - попут дигиталне технике, образовања на даљину или мобилног рада - догађају велики скокови

4 Јелена Митровић, „Развојна библиотерапија као вид промовисања креативног читања и њена примена у библиотеци", Глас библиоиеке 20 (2014), http://www.cacak-dis.rs/elektronska_ izdanja/gb20/83-96-gb20-jelena-mitrovic.pdf (преузето 15. 8. 2020). 
унапред, већ и да ће наша хумано-социјална иниеелиіенција помоћи да се преброди криза."

Дигитализација и дигитална трансформација могу се видети као начин за превазилажење проблема у пословању у претходном периоду, али и као дугорочнија решења која ће омогућити континуитет у раду и окретање ка новим сервисима.

Мередит Фаркас (Meredith Farkas) види библиотеку као место сусрета у виртуелном и реалном простору и дефинише четири основна типа онлајн заједница: заједнице интересовања, заједнице акције, локалне заједнице и заједнице одрживости. Библиотека јесте место сусретања људи који воле књигу и читање, али промена у друштву може да услови да се мења начин на који се афинитети реализују. ${ }^{6}$

Стога се корисници путем друштвених мрежа могу окупити у заједницама интересовања које превазилазе локални карактер. На тај начин чланови истовремено прате програмске садржаје са потенцијалном публиком која је километрима удаљена, а жели да оствари чврсту везу са својим завичајем. Са друге стране ствара се још јача повезаност за заједницом одрживости с обзиром на то да се у њу удружују људи који се већ познају и желе да сачувају своје заједништво.

Дакле прилика и могућности за активнији, једноставнији и обимнији ангажман публике једне, на пример институције културе, данас има више него у добу пре интернета, али овај потенцијал остаје недовољно искоришћен уколико се корисничкој партиципацији не приступи стратешки, плански и истраживачки. „Оно што најбоље повезује критичку библиотекарску мисао на различитим крајевима света јесте уверење да будућност библиотека није само технолошко, већ много више друштвено и вредносно питање. Савремена библиотека није пасивни отисак окружења, већ жива и динамична институција, произвођач нових услуга и вредности."

Dojče vele, „Španska groznica: pouke za budućnost”, https://www.dw.com/sr/\%C5\%A1panskagroznica-pouke-za-budu\%C4\%87nost/a-53266162 (preuzeto 12. 8. 2020).

6 Тамара Вученовић, „Дигиталне комуникације и публика”, Кулитура бр. 164 (2019): 274-275.

7 Гордана Стокић-Симончић и Жељко Вучковић, Менаименй у библиотекама (Београд: Стокић- Симончић, Вучковић, 2003), 56. 


\section{Српске библиотеке на друштвеним мрежама}

Већина установа културе у Србији своје програмске садржаје требало је да прилагоди новонасталој здравственој ситуацији. Иако погођене отказивањем манифестација, различитих садржаја од књижевних вечери, изложби, концерата па до представа, пред све установе је постављен задатак како да што ефикасније преброде кризу и не одустану од своје мисије. О финансијским последицама вероватно ће се тек радити опсежније студије, нарочито о периоду пролеће/лето, када је контакт са публиком врло учестао. Евидентно је да свако ко је желео да сачува везу са својом публиком брзо је морао одреаговати у реогранизацији посла и измештању програмске активности на интернет. Установе су на различите начине од виртуелних тура, онлајн манифестација па до представа које су се могле гледати на њиховим Јутјуб каналима омогућавале приступ квалитетном културном садржају.

И онда када су врата јавних библиотека у Србији била затворена за кориснике, њихови дигитални сервиси били су доступни: завичајне дигиталне колекције, репозиторијуми, е-књиге и сл. Библиотекари су посебно усмерили пажњу на чување контакта са најмлађим корисницима те су стручни радници из библиотека у Пожеги и Лесковцу читали бајке, басне и друге сликовнице за најмлађе, усмеравајући их ка правим вредностима путем заборављених, али и популарних прича, уживо их емитујући на својим друштвеним мрежама. Народна библиотека Србије је организовала у августу, први пут, онлајн трибину посвећену музичару Милану Младеновићу. А у Библиотеци града Београда интензивно се месецима реализују различити виртуелни циклуси: „Читам, не скитам! Са књигом се сликам!”, „Прочитај ми моју жељу”, „Причам, не скитам”, а од септембра на друштвеним мрежама установе библиотекари су покренули виртуелни „Споменар БГБ”.

У Народној библиотеци у Крагујевцу током августа започет је циклус онлајн књижевних програма „Књижарење”.

\section{Начуљи уши, читам ти причу!}

Прича и причање још од времена легендарне Шехерезаде па до данас један је од најделотворнијих начина повезивања људи, а слушање прича код куће, на отвореном, поред реке или на неком пријатном месту је својеврстан лек за душу. 
Као што је истакао наш велики писац Иво Андрић, у Беседи приликом уручења Нобелове награде, потреба за причом и причањем остаје и причању нема краја... „Није уопште толико важно да ли један приповедач описује садашњост или прошлост, или се смело залеће у будућност; оно што је притом главно, то је дух којим је надахнута његова прича, она основна порука коју људима казује његово дело. А о томе, наравно, нема и не може бити прописа ни правила. Свак прича своју причу по својој унутарњој потреби, по мери својих наслеђених или стечених склоности и схватања и снази својих изражајних могућности; свак сноси моралну одговорност за оно што прича, и сваког треба пустити да слободно прича. Али допуштено је, мислим, на крају пожелети да прича коју данашњи приповедач прича људима свога времена, без обзира на њен облик и њену тему, не буде ни затрована мржњом ни заглушена грмљавином убилачког оружја, него што је могуће више покретана љубављу и вођена ширином и ведрином слободног људског духа. Јер, приповедач и његово дело не служе ничем ако на један или на други начин не служе човеку и човечности. То је оно што је битно."

Руководећи се мудрим речима нашег нобеловца и принципима библиотерапије, креирана је летња програмска шема Библиотеке „Начуљи уши, читам ти причу!”

Важно је напоменути да су све приче снимљене у просторијама Библиотеке и да су целокупан процес одабира материјала, читања, студијског снимања звука, обраде и монтаже и визуелног сегмента искључиво урадили библиотекари. Одабране су пригодне приче, дела епистоларне књижевности, кратки есеји, погледи, цртице домаћих и страних стваралаца. Приликом одабира текстова идеја је била да буду заступљене приче које су пре свега занимљиве, духовите, са сатиричним погледом на друштво, али и текстови који побуђују најтананије емоције и враћају у прошлост. Посебан изазов био је одабрати део писама којима се, кроз приповедање у првом лицу, лако проналази пут до срца слушалаца. Која год форма текста да је у питању, важно је било да се истиче својом универзалношћу, квалитетом и обимом, а сваки снимљени аудио-запис да траје најдуже пет минута. У првом сегменту током августа заинтерсовани слушаоци су могли да чују дела из пера Марине Цветајеве, Бранка Миљковића, Бранислава Петровића,

8 Пројекат Растко, „О причи и причању: Беседа Иве Андрића поводом доделе Нобелове награде за књижевност 1961. године”, Зоран Стефановић, https://www.rastko.rs/rastko/ delo/10110 (преузето 25. 8. 2020). 
Матије Бећковића, Оливере Недељковић, Ивана Токина, Богдана Стевановића Блогдана...

Свесни чињенице да библиотекари могу да одаберу добре приче, али да немају велике ресурсе када је у питању студијска опрема, тражен је начин да се добије квалитетан звук и целокупан снимак, а да та програмска активност не захтева додатни буџет. Стога је искоришћена постојећа техника (коју би ваљало да има свака јавна библиотека): кондезаторски микрофон, сталак за микрофон, поп-филтер, дигитална миксета, лаптоп, слушалице, као и програм за аудио-снимање.

Постоје многи квалитетни програми за аудио-монтажу, али је њихово инсталирање потребно платити, стога је одабран одличан бесплатни програм који нуди све потребне операције над аудио-датотекама. Програм Audacity се може преузети и инсталирати на рачунару. То је један од најпопуларнијих програма отвореног кода за снимање звука и његову накнадну обраду. Важна карактеристика је да ради на свим оперативним системима и да подржава све познате аудио-формате као што су MP3, AVI, MPEG, WAV и др. Овим програмом се веома једноставно може снимити глас, а квалитет снимка ће зависити од микрофона. Снимљено се може накнадно мењати, додавањем различитих ефеката. Када су у питању лошији микрофони, буку у позадини није лако избећи (шумови, дисање и сл.), међутим помоћу овог програма негативни утицаји се једноставно могу уклонити.

Најпре је потребно да се у снимку пронађе део на коме се искључиво чује шум. То може, на пример, да буде пар секунди у којима се прави пауза и тај део снимка на коме се чује искључиво позадинска бука требало би означити и одабрати опцију Effect - Noise Removal, а затим кликнути на Get Noise Profile. Сада је програму речено која би „шум” требало да се уклони. У следећем кораку обележава се цео снимак, и поново се кликнете на Effect Noise Removal, па на ОК. На крају је важно напоменути да након извршених промена треба кликнути на опцију File - Export, како би све било снимљено у жељеном аудио-формату. Програм је идеалан за почетнике и све који раде основну обраду звука, а може се преузети са сајта Audacity. ${ }^{9}$

Након урађеног комплетног аудио-концепта, приступило се читању одабраних текстова и аудио-обради тог материјала, а након тога записи су монтирани у програму Movie Maker. За целокупан процес монтаже било је потребно снимити оригиналне фотографије које су представљале део

9 Audacity, https://www.audacityteam.org/ (преузето 25. 8. 2020). 
визуелног идентитета летње програмске шеме и одабрати музику која је дозвољена за преузимање, тј. не подлеже ауторским правима.

Као што је већ напоменуто, аудио-записи су емитовани на Фејсбук страници и Јутјуб каналу установе сваког уторка, четвртка и суботе од 21 час. Целокупан аудио-концепт, избор текстова урадиле су и читале Марија Радуловић и Тања Вуковић, постпродукцију потписује Мирко Дрманац, а за фотографију и монтажу био је задужен Владимир Симић.

\section{Библиотека доскочила корони ${ }^{10}$}

У тренутку када је медијски простор био загушен информацијама о броју заражених вирусом корона, политичким и економским темама, а рубрике за културу готово невидљиве, није било лако привући пажњу седме силе летњом програмском шемом „Начуљи уши, читам ти причу!” коју је једино било могуће спровести онлајн. Аутори су били свесни да број прегледа (публике) зависи од комплетног промовисања летње шеме, стога је било важно направити добар маркетиншки план, одабрати друштвене мреже, термине за емитовање аудио-записа и створити препознатљив визуелни идентитет.

Саопштење о почетку емитовања „Начуљи уши, читам ти причу!” прослеђено је локалним, регионалним и националним медијским кућама и упркос релативно малом простору за информације из света културе, новинари су ову вест пренели на дванаест интернет портала. Објављена су два текста у штампаним медијима, у недељнику Чачански ілас и дневном листу Политикка. Прилог је емитован на регионалној телевизији „Лав плус” и на неколико локалних радио-станица. Такође ову акцију су подржале и издавачке куће, а на сајту „Лагуне” објављена је најава летње програмске шеме.

Градску библиотеку су након медијске промоције и емитовања прве приче на друштвеним мрежама позивали представници различитих удружења подржавајући акцију, са жељом да остваре дугорочнију сарадњу и дарују аудио-књиге.

Библиотека је и раније била препозната као установа која реагује на актуелне проблеме и креира нове сервисе и садржаје кроз додатно деловање

10 Назив поглавља који даје анализу резултата летње програмске шеме инспирисан је једним од упечатљивијих медијских наслова, https://www.cemaforum.rs/sr/vest/1710/Biblioteka-u\%C4\%8Ca\%C4\%8Dku-dosko\%C4\%8Dila-koroni:-Na\%C4\%8Dulji-u\%C5\%A1i-\%E2\%80\%93\%C4\%8Ditam-ti-pri\%C4\%8Du!--/ (преузето 11. 8. 2020). 
и укључивање у свакодневни живот грађана. То потврђује и заинтересованост аудиторијума да прати онлајн садржаје Библиотеке, те је за месец дана емитовања аудио-записа одабраних прича било више од 2.300 прегледа.

Новом летњом шемом Библиотеке настављен је континуитет рада, проширен је опсег програмских активности и омогућена је доступност културе и културних садржаја и у време када је окупљање публике једино било могуће организовати на друштвеним мрежама и интернету.

\section{Закључак}

Летња програмска шема „Начуљи уши, читам ти причу!” представља нов, ауторски производ библиотекара, настао као плод кадровских и техничких потенцијала установе, али и ограничења и мера које се већ неколико месеци активно примењују услед последица пандемије. Сличним акцијама шаље се јасна порука да се култура не може заустиавитии. Нарочито су се у програмском делу догодиле многе трансформације. Биле су неопходне брзе реакције у преосмишљавању садржаја намењених публици.

Иако је културна сцена изашла из каранииина 24. августа, и даље се пажљиво планирају и спроводе програмски садржаји, са одређеном дозом резерве шта нас чека у новом таласу вируса корона, тј. колико ће се поново активности и садржаји мењати. Са друге стране, економске последице изазване пандемијом јасно су видљиве у свим сферама живота, а посебно у култури, јер су буџети за организацију програмске делатности многих великих позоришних и оперских кућа значајно умањени, а вероватно ће бити слична ситуација и са другим установама културе (музејима, галеријама, библиотекама итд.). Имајући и финансијски ефекат у виду, непрестано се мора ићи ка новим решењима и тражити начин како да се превазилазе проблеми, јер култура би требало да буде у служби грађана без обзира на кризу. 


\section{Literatura:}

1. Dojče vele, „Španska groznica: pouke za budućnost”, https://www.dw.com/sr/\%C5\%Alpanska-groznica-pouke-za-budu\%C4\%87nost/a-53266162 (preuzeto 12. 8 . 2020).

2. Mitrović, Jelena. „Razvojna biblioterapija kao vid promovisanja kreativnog čitanja i njena primena u biblioteci". Glas biblioteke 20 (2014) http://www.cacak-dis.rs/ elektronska_izdanja/gb20/83-96-gb20-jelena-mitrovic.pdf (preuzeto 15. 8. 2020). (na ćirilici)

3. Pravno-informacioni sistem RS. „Odluka o ukidanju vanrednog stanja: 65/2020-4”. https://www.pravno-informacioni-sistem.rs/SlGlasnikPortal/eli/rep/sgrs/skupstina/odluka/2020/65/1/reg (preuzeto 3. 8. 2020). (na ćirilici)

4. Projekat Rastko. „O priči i pričanju: Beseda Ive Andrića povodom dodele Nobelove nagrade za književnost 1961. godine". Zoran Stefanović. https://www.rastko.rs/ rastko/delo/10110 (preuzeto 25. 8. 2020). (na ćirilici)

5. Stokić-Simončić, Gordana i Željko Vučković. Menadžment u bibliotekama. Beograd: Stokić-Simončić, Vučković, 2003. (na ćirilici)

6. Vlada Republike Srbije. „Striktno poštovati zabranu okupljanja”. https://www.srbija.gov.rs/vest/450393/striktno-postovati-zabranu-okupljanja.php (preuzeto 25. 8 . 2020). (na ćirilici)

7. Vučenović, Tamara. „Digitalne komunikacije i publika”. Kultura br. 164 (2019): 274-275. (na ćirilici) 


\title{
Marija V. Radulović
}

marijaradulovic3@gmail.com

\section{Tanja M. Vuković}

vukovic.tanja1@gmail.com

Public Library “Vladislav Petković Dis”, Čačak

\section{A STEP FORWARD INTO THE ONLINE WORLD Activities of the Public Library in Čačak During the Coronavirus Pandemic}

\begin{abstract}
Ever since a state of national emergency has been declared in the Republic of Serbia, due to the coronavirus pandemic, many things have changed in the domain of culture. Even though affected by the cancellation of various events: literary evenings, book promotions, exhibitions, public discussions, workshops, and so on, public libraries were tasked with overcoming the crisis and not giving up on their mission. This paper presents the activities of the Public Library "Vladislav Petković Dis" in Čačak from March to September 2020, with special emphasis on the programs that have been organized in new circumstances caused by the health situation. Among other things, there are examples of how some of the Serbian libraries recompensed the lack of program activities by stepping into the online world. Having become a creator of new services and values, the Čačak Public Library designed a summer program "Listen carefully, I am reading you a story!" that was broadcast on the Library's Facebook page and YouTube channel during August and September. The new summer program scheme ensured the continuity of the work and expanded a range of activities, making cultural content available at the time when audience gatherings could only be organized on social networks and the internet. Activities like this send a clear message to the public that culture is unstoppable.
\end{abstract}

Keywords: Public Library in Čačak, coronavirus, online program, social networks, program activity, audio recording.

Примљено: 10. септембра 2020.

Прихваћено: 15. октобра 2020. 